\title{
AFINIDADES POÉTICAS: A VONTADE DE CINEMA NA LITERATURA, O DESEJO DE LITERATURA NO CINEMA
}

\section{POETIC AFFINITIES: THE WILL TO CINEMA IN LITERATURE, THE DESIRE FOR LITERATURE IN CINEMA}

\author{
João Manuel dos Santos Cunha*
}

RESUMO: Este texto examina a leitura operada pelo cineasta Joaquim Pedro de Andrade - O padre e a moça (1965) - para o poema de Carlos Drummond de Andrade - "O padre, a moça" (1962). Por meio dessa aproximação, o que se quer comprovar é a permanência da poesia, vista como condição inerente aos dois textos, na passagem do "negro amor de rendas brancas" de uma a outra textualidade. Nesse percurso, fica ainda evidente que, desde o início da centenária relação entre as duas linguagens estéticas, não só o cinema explicitou sua "vontade de literatura", como o "desejo de cinema" sempre esteve presente na literatura. PALAVRAS-CHAVE: Literatura comparada, literatura e cinema, Carlos Drummond de Andrade, Joaquim Pedro de Andrade, O padre e a moça.

ABSTRACT: This text examines a reading by movie director Joaquim Pedro de Andrade of a poem by Carlos Drummond de Andrade (respectively, O padre e a moça [The Priest and the Girl, 1965] and "O padre, a moça" ["The Priest, the Girl", 1962]). Through this approximation, we attempt to prove that poetry remains as an inherent condition to both texts, as this "negro amor de rendas brancas [dark love in white lace]" goes from one mode of textuality to another. In this process, it becomes clear that, ever since the beginnings of the century-old relationship between the two aesthetical languages, not only has cinema made its "will to literature" explicit, but also literature has always implicitly had a "desire to cinema".

KEYWORDS: Comparative literature, literature and cinema, Carlos Drummond de Andrade, Joaquim Pedro de Andrade, O padre e a moça [The Priest and the Girl, 1965].

\footnotetext{
* Universidade Federal de Pelotas (UFPel), Pelotas/RS. Professor Adjunto do Centro de Letras e Comunicação (CLC). Doutor em Literatura Comparada pela Universidade Federal do Rio Grande do Sul (UFRGS). Pós-Doutor em Literatura e Cinema na Universidade de Paris III - Sorbonne-Nouvelle, Paris, França. Email: jm_sc@terra.com.br.
} 



\section{AFINIDADES POÉTICAS: A VONTADE DE CINEMA NA LITERATURA, O DESEJO DE LITERATURA NO CINEMA}

\section{Introdução}

Stéphane Mallarmé observou que "o mundo existe para acabar num livro", tese que o cineasta Jean-Luc Godard encampa, em uma outra visada, ao assegurar, citando André Bazin, que "o mundo existe para se acomodar aos nossos desejos". Tais asserções apontam para a reafirmação de quanto abrangente e ambicioso é o projeto humano de transcender a realidade, criando com palavras e com imagens mundos que serão eternos e universais na medida em que forem descobertos, interpretados e articulados em linguagem. Descartando, por não se conformarem com o método comparatista contemporâneo, quaisquer fronteiras epistemológicas e estéticas para a leitura conjunta de textualidades verbais e imagéticas e partindo do pressuposto de que textos literários e fílmicos ${ }^{3}$ resultam do olhar interpre-

1 Frase extraída de entrevista concedida pelo poeta a Jules Huret, em 1891, para o jornal L'Echo, de Paris, e reproduzida posteriormente em Magazine Littéraire: Mallarmé, Le monde est fait pour aboutir à un beau livre, Enquête sur l’évolution littéraire, Bibliothèque Carpentier, Paris, 1891, p. 55-65.

2 No incipit fílmico de O desprezo (Le mépris, França, 1963), em off, Godard retoma o célebre aforismo: "Le cinéma, disait André Bazin, substitue à notre regard um monde qui s'accorde à nos désirs". Tanto na paráfrase de Godard quanto em Bazin, a expressão "nossos desejos" abrange não apenas os pessoais e íntimos, mas, precipuamente, os sociais.

3 É pacífica a ideia, na teoria do cinema contemporânea, de que o texto fílmico tem autonomia 
tante do sujeito sobre o mundo, este texto examina a leitura operada pelo cineasta Joaquim Pedro de Andrade - O padre e a moça (1965) - para o poema de Carlos Drummond de Andrade - "O padre, a moça" (1962). Por meio do exercício analítico-comparativo, o que se quer comprovar é a permanência da poesia, vista como condição inerente aos dois textos, na passagem do "negro amor de rendas brancas" de uma a outra textualidade. Nesse percurso, ficará ainda evidente que, desde o início da centenária relação entre as duas linguagens estéticas, não só o cinema explicitou sua "vontade de literatura", como o "desejo de cinema"4 sempre esteve presente na literatura.

\section{Entre o branco e o preto, há luz: a natureza poética da escrita fílmica}

Jean Cocteau, poeta e cineasta, considerava que a imagem fílmica é escritura ${ }^{5}$ feita com "uma tinta de luz" - "une encre de lumière" -, referindose não àquilo que está escrito, mas ao que se vê: quer dizer, um texto de luz apenas perceptível por um olhar iluminante desde o nosso interior (Apud BRETĖQUE, 1989, p. 7). Essa luz não seria a banal e cotidiana luminosidade de nossos dias, mas a do astro lunar que clareia as noites e os nossos sonhos. O aparente lugar-comum nos permite pensar o cinema como uma escrita de signos negros projetados com "tinta negra" sobre o branco da tela, superfície em que se desenham, provisoriamente, formas em movimento. A claridade que possibilita a existência dessas imagens não é, entretanto, para Cocteau, apenas a da luz lunar de nosso misterioso astro interior, mas também a da luz elétrica dos holofotes nos plateaux de

de código narrativo textual, principalmente após as reflexões desenvolvidas a partir dos anos 1960 por Christian Metz: "O cinema não é uma língua, sem dúvida nenhuma, mas pode ser considerado como uma linguagem, na medida em que ordena elementos significativos no seio de combinações reguladas, diferentes daquelas praticadas pelos idiomas e que também não decalcam a realidade. Assim, sendo uma linguagem, permite uma escrita, isto é, o texto fílmico" (1980, p. 338; grifo do autor).

4 Uso a expressão a partir da assertiva de Francis Ramirez, quando ele examina a repercussão do imaginário fílmico na poesia de Guillaume Apollinaire, in: Apollinaire et le désir de cinéma, Cahiers de l'Association Internationale des Études Françaises, 1995, p. 371-379.

5 O uso do termo "escritura" (écriture) em Cocteau tem mais a ver com a concepção que remonta às vanguardas francesas (a "caméra-stylo" de Alexandre Astruc e o "cinécriture" de Louis Delluc) do que com construções posteriores, como a de Roland Barthes no ensaio O grau zero da escritura (Le degré zéro de lécriture, 1953). 
filmagem e da que é projetada pelos rebatedores de luz solar, semelhante ao claro da lua, em seus matizes leitosos e com seus contrastes claro-escuros. Creio que seja essa uma das mais poéticas - e ao mesmo tempo precisas - definições de cinema em preto e branco, formulada por um escritor e cineasta que jamais filmou em cores. ${ }^{6}$ Traçar signos com tinta negra sobre o branco do écran seria, assim, um ato de escritura, produção textual que só existe entre a claridade e a obscuridade.

O cinema, tal como foi visto e pensado pelas vanguardas francesas, localiza-se naturalmente na alta modernidade poética, eis que o filme não falado, em preto e branco, ao traduzir em imagens reflexões e lembranças articuladas como memória do mundo sensível, aparece não como um modo de representação do universo, mas como uma janela aberta sobre um outro mundo desejado. Um mundo ocupado por rostos esbranquiçados - visages crayeux (Apud RAMIREZ, 1995, p. 36), objetos animados, espectros diáfanos, surpreendidos em imagens ralentadas e movimentos em retrocesso. Vistos assim, os motivos da escrita cinematográfica são eminentemente fantasmáticos, circunstância que, com naturalidade, instala o poeta modernista em terreno de seu domínio: o de uma realidade imaginada, a que ele tem acesso ao atravessar a "lucarna do infinito" - "la lucarne de l'infini" -, na expressão pioneira de Charles Baudelaire.

O encontro do cinema com a poesia aparece, assim, desde logo, como profundo e profícuo. A poesia prolonga sua exploração estética no cinema; e o cinema recebe a unção da poesia na busca e na definição de sua especificidade estética. Creio que é bastante conhecida a prática poética das vanguardas francesas de aproximação da literatura com as incipientes

\footnotetext{
${ }^{6}$ Comentando a produção de seu filme O testamento de Orfeu (Le testament d'Orphée, 1960), Jean Cocteau vai dizer: "Le noir et blanc statufie les personnages et les lieux. Les films en noir et blanc profitent d'une sortie de clair de lune, de cette lune dont jécrivais jadis qu'elle est le soleil des statues. [...] Les couleurs d'un film ressemblent à l'artifice des fleurs afin d'attirer les insectes. Ce serait insulte à notre public que de lui tendre ce piège et j'y renonce." Cf. Jean Cocteau, Noir et couleur, in : Une encre de lumière, [1960] 1989, p. 83.

7 É para referir-se a estereoscopia, processo fotográfico que produz efeito tridimensional graças à utilização de dois registros simultâneos, em duas perspectivas diferentes do mesmo assunto, procedimento técnico precursor da captação e da projeção de imagens fílmicas, a partir do qual Baudelaire cria a expressão. Cf. Charles Baudelaire, in: Le public moderne et la photographie, Salon de 1859, [Revue Française, 1859], Oeuvres completes, 1961, p. 1.031-1.086 ; Salão de 1859, in: Obras estéticas, filosofia da imaginação criadora, 1993, p. 83-147.
} 
conquistas da linguagem fílmica e com o imaginário cinematográfico do início do século XX. Dessa convergência estabelecida desde os inícios, marcas podem ser rastreadas na obra de poetas como Guillaume Apollinaire, Max Jacob, Jean Cocteau, Pierre Albert-Birot, Blaise Cendrars, Robert Desnos, Phillipe Soupault, Henri Michaux, chegando até Jacques Prévert e Raymond Queneau. ${ }^{8}$ Isso para não falar da visionária e consequente lição dos surrealistas, os quais encontraram no cinema uma espécie de "nova terra prometida da poesia" (RAMIREZ, 1995, p. 376). ${ }^{9}$ Essas conexões intertextuais se configuram não só pela recorrência a temas inerentes ao processo cinematográfico, como também pela experimentação verbal conformada aos procedimentos fílmicos. Convenientemente, a "nova poesia" francesa encontra no cinematógrafo correspondências para o seu programa renovador: "novo" realismo, dadaísmo, rapidez, síntese, humor, simultaneísmo e liberação do subconsciente pela ruptura da ordem da ação mais do que da do pensamento. Em oposição aos "filmes de arte", adaptados de Victor Hugo, Musset, Zola e tantos outros representantes da "grande literatura”, os poetas preferem as imagens céleres, inconsequentes e sem pretensão educativa, que lhes fornecem ampla provisão do "lirismo do acaso" - "lyrisme de hasard"10 - que eles iam buscar nas salas dos "panoramas"11

8 Em A lição aproveitada: cinema e modernismo em Mário de Andrade, 2011, analiso em profundidade as relações dos poetas vanguardistas franceses com a poética do cinematógrafo e a repercussão do pensamento desses escritores-críticos na obra literária dos modernistas brasileiros de forma geral e, especificamente, na de Mário de Andrade.

9 Para detalhamento dessas relações, ver João Manuel Cunha, Avant-garde, literatura e cinema, in: O olho da História, 2004, p. 1-19; também disponível em www.oolhodahistoria. ufba.br.

10 Cf. Francis Ramirez (1995, p. 33). A expressão foi usada por Louis Aragon, em Anicet ou le Panorama, primeiro romance do autor, de 1921. O texto reflete a vida cotidiana pela poetização de elementos do mundo contemporâneo, a partir da revista semanal de aventuras de Nick Carter, dos filmes americanos de Pearl White e do seriado francês Fantomas. As cenas desenvolvidas na "Passage du Cosmorama" e na "Passage du Panorama" prefiguram os cenários de sua obra-prima, o "romance cinematográfico" O camponês de Paris (Le paysan de Paris, 1926).

${ }^{11} \mathrm{O}$ panorama prenunciou a chegada das imagens cinematográficas. Patenteado pelo escocês Robert Barker, em 1787, localizava-se em uma rotunda, especialmente construída para esse fim, onde era instalada uma tela pintada, em 360 graus, dando a volta, internamente, no edifício. Ao centro, uma plataforma, onde se postavam os observadores. A experiência, permanentemente aperfeiçoada, só foi se tornar popular ao final do século XIX. Era compartilhada em conjunto, por um público pagante, uma plateia de espectadores. $\mathrm{O}$ espetáculo consistia na produção de efeitos óticos provocados pela luz natural (ou artificial), 


\section{e dos cinematógrafos nos boulevards e nas galerias (passages) francesas. ${ }^{12}$}

que atravessava a tela, onde eram pintadas as mais diversas "vistas" naturais, cenas de batalhas, feitos históricos. As linhas de limitação superior e inferior, na junção da tela com o edifício, eram mascaradas para dar a ilusão de uma paisagem ou de um acontecimento real. Este era o objetivo: a confusão entre ilusão e realidade como fundamental para a magia do espetáculo. Segundo François Robinchon, "os panoramas não são outra coisa que uma maneira de expor uma grande tela, de forma que o olhar do espectador, que tem o seu horizonte completamente abarcado, não encontra os limites do que é a tela, e assim ele experimenta a mais completa ilusão" (1985, p. 65). Walter Benjamin considerou que "por mil artifícios técnicos, [o panorama] aventura-se infatigavelmente a fazer perfeita imitação da natureza. Ao recorrer à ilusão por reproduzir fielmente as mudanças naturais, os panoramas anunciam, além da fotografia, o cinema" (2006, p. 60). Essa tecnologia de representação visual de uma realidade imaginada foi aperfeiçoada, de forma requintada e popularmente consagrada, até o início do século XX, por meio de técnicas cada vez mais avançadas que permitiam a instalação dos dispositivos em espaços menores, como em galerias comerciais e nas labirínticas passagens das cidades modernas. Transitando por elas, o flâneur de Baudelaire, sujeito imagético por excelência, inventa a modernidade, transitando entre lugares e tempos, confundindo-se entre interior e exterior, entre passado e presente, entre o próximo e o longe, entre realidade e imaginação. Para mais informações sobre panorama e diorama, ver: Bernard Comment, Le XIXe siècle des panoramas, 1993; François Robichon, Le panorama, spectacle de l'histoire, 1985.

${ }^{12}$ Walter Benjamin produziu uma série de textos sobre a vida pública na Paris finissecular em direção ao século XX, escritos entre 1927 e 1940, mas publicados em conjunto somente em 1982, na Alemanha, sob a denominação de Das Passagen-Werk, título próximo de seu projeto inacabado, a que ele intitulara de "Passagenarbeit", ou seja, "Trabalho das passagens". Traduzido a partir do final do século em diversas línguas, o volume das Passagens, tal como hoje é conhecido, compõe-se de uma exuberante coletânea de esboços, notas e materiais diversos, agrupados por módulos temáticos e organizados em arquivos por ordem alfabética. Por meio da análise do vai e vem pelos espaços públicos das "passagens", "arcadas" ou "galerias comerciais", vistas como "arquipaisagem do consumo", é apresentada a história cotidiana da modernidade a partir de Paris, centrada em figuras como as do flâneur e da prostituta, do jogador e do colecionador, fixada por meio de uma escrita polifônica que abrange desde a luta de classes até os fenômenos da moda, das técnicas de reprodução e do progresso dos meios de comunicação de massa. No fragmento "Passagens parisienses" (interrompido em 1929), há um arquivo específico (Konvolut Q) dedicado aos "panoramas" (espaços circulares em que espectadores assistiam a "vistas animadas, pintadas em profundidade de campo, percebidas em simultaneidade", que prefiguravam as primeiras imagens públicas dos cinematógrafos), dos quais ele dirá serem "a expressão de um novo modo de existência", observando uma "reviravolta na relação entre a arte e a técnica". Para ele, o panorama foi precursor da cinefotografia, em sua tentativa de capturar e representar o tempo e condensar o espaço, por superposição de planos. É nessa "cidade-paisagem" criada pelos panoramas que o flâneur encontrará os motivos de sua poesia cotidiana. Não por acaso, logo as salas de cinematógrafos ocupariam o lugar dos panoramas nas galerias que misturavam a rua e o interior, o público e o privado. Não é por acaso, também, que a metodologia de sua historiografia "imagética" da modernidade constitua-se na forma de 
No contexto dessas relações eletivas e afetivas, um nome aparece como unanimidade de diretriz poética: o de Charlie Chaplin, confundido com seu personagem Carlitos e onipresente nas telas do cinema mudo até o final dos anos 1930. Não é o caso de atualizar aqui a amplitude e o alcance dessa eleição entre os poetas franceses, que poderia ser sintetizada na expressão do poeta Henri Michaux: "Charlie, c'est nous" (Apud RAMIREZ, 1995, p. 33).

\section{A lição do cinema e a poesia modernista}

No Brasil, é a obra de Mário de Andrade que resume a estreita relação de nossas vanguardas literárias com a estética cinematográfica. Ainda que se possa verificar e confirmar essa ligação da poesia brasileira modernista com a linguagem fílmica, agudizada em poemas de Oswald de Andrade e de Luis Aranha, ${ }^{13}$ por exemplo, é com Mário que a experimentação vai produzir não só uma poesia configurada ao processo e aos procedimentos fílmicos, como também uma reflexão consistente sobre essa prática intertextual. Ele é um daqueles escritores modernos nos quais Leyla Perrone-Moisés reconhece o exercício de uma "poética sincrônica", porque, além de poesia, estabeleceram, "eles mesmos, seus princípios e valores, e passaram a desenvolver, paralelamente às suas obras de criação, extensas obras de tipo teórico e crítico" (1998, p. 11). Leitor de poetas e teorizadores da vanguarda francesa, como Philippe Soupault, Blaise Cendrars, Jean Epstein, Louis Aragon e Jean Cocteau, é com os textos deles que os seus vão dialogar reiteradamente. Em ensaio de 1922, por exemplo, intitulado "A escrava que não é Isaura (Discurso sobre algumas tendências da poesia modernista)", discutindo as relações entre as artes, ele conduz a reflexão a partir de comentários retrospectivos sobre a história da música e das artes plásticas, aproximando-se das teorias de Ricciotto Canudo a respeito de "arte pura". O poeta e teórico ítalo-francês defendia a ideia de que o processo evolutivo

uma montagem de fragmentos, imagens e citações: formalmente, a estrutura "literária" dos arquivos dispostos em Passagens remete para a montagem das imagens tecnológicas tal como a técnica e a estética cinematográficas vinham desenvolvendo por esse tempo. Sobre a reflexão de Benjamin sobre os panoramas e a representação imagética pela montagem fílmica, ver, além do fichário citado, em Passagens, "Passagens parisienses" I e II; "Paris, capital do século XIX”, in: Walter Benjamin, Passagens ([1927-1929], [1934-1940]), 2006; ainda: S. Buck-Morss, Dialética do olhar, Walter Benjamin e o projeto das passagens, 2002.

${ }^{13}$ De quem Mário de Andrade disse ser "um filho da simultaneidade contemporânea" (1980, p. 273), da mesma forma como lia na obra de franceses como Soupault, Cendrars, Cocteau, Beauduin e Tzara a repercussão do efeito do simultaneísmo cinematográfico. 
das artes culminou, no século XX, com a criação do cinema, a que ele vai chamar de "sétima arte". ${ }^{14}$ Só que a leitura andradina para as formulações de Canudo, e em oposição também às ideias de Jean Epstein, transcende à mera sucessibilidade das artes, eis que ele compreendeu que foi justamente o cinematógrafo que possibilitou a descoberta de que "a obra de arte é uma máquina de produzir comoções" (1980, p. 258).

Mário postula, também, que, sendo a cinematografia a representação da vida em sua "simultaneidade visual", tal como ele próprio proclamara no número inaugural da revista Klaxon, e "realizando a vida como nenhuma arte ainda o conseguira", foi ela "o Eureka! das artes puras" (1980, p. 258). Seu reconhecimento de que o cinema liberara as outras artes para a qualidade de "pureza", tema caro às vanguardas do início do século XX, entretanto, coloca o caráter cinematográfico da simultaneidade como fator fundamental para a renovação dessas mesmas "artes puras". Se, para Mário, "simultaneidade é a coexistência de coisas e fatos num momento dado" (1980, p. 268), está implícita em seu discurso a concepção de que o simultaneísmo, resultante da sucessão de imagens no tempo, aproxima-se do que, para ele, seria crucial para todo poeta: "[...] realizar a simultaneidade do eu e do mundo exterior, [alcançando] o sentimento complexo da vida" (1980, p. 259). Como poeta, realiza esse desejo nos poemas de Clã do jaboti e Losango cáqui. ${ }^{15}$ Convencido de que a "simultaneidade será uma das maiores senão a maior conquista da poesia modernizante" (1980, p. 273), busca praticar o que, ao mesmo tempo, propõe teoricamente, produzindo sua "literatura de circunstância", ${ }^{16}$ concernente com o "lyrisme de hasard", evocado pelos fran-

\footnotetext{
${ }^{14}$ Sobre essa articulação entre cinema e artes clássicas, ver: Ricciotto Canudo, L’usine aux images, 1927.

${ }^{15}$ Os poemas de Clã do jaboti foram escritos entre 1922 e 1926 e publicados em livro em 1927, e os de Losango cáqui, produzidos em 1922 e publicados em 1924, segundo informação do próprio autor em "Prefácio" para edição do livro em 1924. Os dois livros encontramse atualmente reunidos em Poesias completas, v. 2, de Obras completas, segundo projeto de edição das obras completas proposto por ele mesmo em 1945. É em "Carnaval carioca”, em Clã do Jabuti, que se encontra um dos mais célebres e paradigmáticos versos de sua poética, "sou um tupi tangendo um alaúde", mas é também aí que ele invoca "Carlitos", como uma figura simbólica do imaginário contemporâneo brasileiro. No livro A lição aproveitada: modernismo e cinema em Mário de Andrade (2011), analiso detalhadamente os traços do "simultaneísmo" nos poemas desses dois livros.

${ }^{16}$ Característica poética invocada pelo próprio Mário de Andrade: “[...] poesia-decircunstância [...] - anotações líricas de momentos de vida”. Cf. "Advertência”, in: Losango cáqui, Obras completas, v. 1, 1980, p. 67.
} 
ceses para designar a sensação poética decorrente da escrita fílmica. Quanto à aplicação dos procedimentos técnicos que produziriam a simultaneidade na literatura, entretanto, a posição do modernista brasileiro difere da dos teóricos franceses: é impossível reproduzir literariamente o que é próprio do específico cinematográfico; o que há é "um transporte de efeito". Ou seja, a montagem de palavras ou de frases proposta pelo escritor é que possibilitaria a impressão de simultaneidade, que não se realiza "em cada sensação insulada mas na sensação complexa total final” (1980, p. 268), tal como acontece no cinema, quando a sucessão de planos é montada na busca de um resultado "realístico transitório, unicamente simultâneo para a sensação total final” (1980, p. 268).

Pode-se dizer que o olhar de Mário de Andrade sobre o mundo redefiniu-se inclusive pelas imagens em preto e branco que ele viu nas salas de cinema. Mas é um olhar criador, o desse Mário cinéfilo. A sua imensa capacidade de ver e de transmitir verbalmente o que vê de forma cinematográfica "consolida, no texto, o olhar da câmera" (LOPEZ, 1991, p. 8). Referências a filmes a que assistiu, fixando-se como componentes de sua experiência estética, encontram-se não só em textos teóricos (como em A escrava que não é Isaura) ou de ficção em prosa (em Amar, verbo intransitivo), mas também em sua produção em versos, desde Paulicéia desvairada (1922) até Lira Paulistana (1944-1945). ${ }^{17}$

No contexto da reiterada aproximação de sua fatura literária à poética fílmica, Mário se alinha aos poetas franceses também quanto à eleição da figura de Charles Chaplin como o representante da modernidade nas artes. A imaginária chapliniana espalha-se lírica e formalmente em seus textos. E aí "Carlitos" é símbolo recorrente. Se é preciso que a literatura aproveite "a lição do cinema", ${ }^{18}$ tal como ele postula no editorial-manifesto de Klaxon,

\footnotetext{
${ }^{17}$ Em “A escalada”, por exemplo, e em “Domingo", de Paulicéia desvairada, em que se refere a quatro atividades típicas da população metropolitana paulista, em um dia de "Futilidade, civilização...”: a missa "de chegar tarde, em rendas"; “o jogo de futebol”/ o corso "das famílias dominicais" e o cinema: "Central. Drama de adultério / A Bertini arranca os cabelos e morre / Fugas... Tiros... Tom Mix!/ Amanhã fita alemã... de beiços/ As meninas mordem os beiços pensando em fita alemã.../ As romas de Petronio... E o leito virginal.../ Tudo azul e branco!/ Descansar... Os anjos... imaculada!/ As meninas sonham masculinidades.../ Futilidade, civilização", in: Paulicéia desvairada, Obras completas, v. I, 1980, p. 33.

18 "A cinematografia é a criação artística mais representativa de nossa época. É preciso observar-lhe a lição", in: Klaxon, n.1, maio 1922; ed. fac-similada, 1976, p. 2.
} 
"Charlie Chaplin é o professor do século XX". ${ }^{19} \mathrm{O}$ multifacetado escritor faz também, de forma pioneira entre nós, crítica de cinema: especificamente sobre o filme O garoto (The kid, USA, 1921), escreve três análises, todas publicadas em Klaxon. ${ }^{20}$ Ao referenciar outros filmes de Chaplin também em textos teóricos, elevou a lírica figura em preto e branco do herói "de cara lívida" 21 (em acordo com a imagem "esbranquiçada" - as "visages crayeux" evocadas pelos vanguardistas europeus) à condição de paradigma para o desenvolvimento de sua "estética da simultaneidade", 22 estruturada a partir da característica de rapidez e síntese fílmicas.

Como se vê, Mário de Andrade coloca-se, pontualmente, na esteira do pensamento poético das vanguardas francesas, não só invocando a cinematografia como a "décima musa", ${ }^{23}$ como também, no que se refere ao estabelecimento de Chaplin/Carlitos como símbolo da modernidade artística, localizando-se no centro da discussão sobre as relações do literário com outros construtos estéticos. Foi esse entendimento que lhe permitiu, como teórico e como poeta, ser dos nossos modernistas o que melhor logrou um diálogo com as vertentes de renovação europeias, as quais, filtradas por seu

${ }^{19}$ Cf. Mário de Andrade, "Uma lição de Carlito", Klaxon, n. 3, jul., 1922, p. 14.

${ }^{20}$ Nas edições de número 2, 3 e 5, junho, julho e setembro, 1922. O filme é um dos três a que ele vai dedicar críticas consistentes entre 1922 e 1923. Os outros dois são o brasileiro Do Rio a São Paulo para casar (José Medina, 1922) e o expressionista O gabinete do doutor Caligari (Das Kabinett des Doktor Caligari, Alemanha, 1919, Robert Wiene). Por indicações rastreadas em outros textos que não críticas cinematográficas formais, é possível identificar os filmes a que ele teria assistido até o final da década. É o caso dos filmes da atriz Pearl White, a qual ele se refere já no primeiro número de Klaxon: para ele, da mesma forma como para o ideário vanguardista europeu, a atriz é "raciocínio, instrução, esporte, rapidez, alegria, vida. Pérola White = século 20".

${ }^{21}$ Em "Arte inglesa" [1943], Mário de Andrade lembra a feição fantasmática que Chaplin criou para a "cara lívida de Carlito". Cf. Mário de Andrade, in: O baile das quatro artes, Obras completas, v. XIV, 1980, p. 169.

22 Em A lição aproveitada: modernismo e cinema em Mário de Andrade, 2011, examino as etapas do desenvolvimento dessa estética andradina, concluindo que o autor, disponível para as influências, receptivo para com um tempo que acumulava novidades em ritmo acelerado, soube selecionar criticamente as ideias que reelaborou para a formulação de sua "estética da simultaneidade", cânone pessoal que vai permear inédita atividade criadora durante todo o primeiro modernismo brasileiro.

${ }^{23}$ Em Crônicas de Malazarte, texto de 1923, Mário revela, liricamente, que "o cinema possui uma nova denominação: vejo as dez musas (sim: há uma décima, nascida neste século, a Musa Cinemática) fugirem espaventadas com o possível renascimento de todos os poetas". Cf. Eduardo Escorel, A décima musa, in Revista Novos Estudos, 1993, p. 171. 
crivo criador, foram adaptadas a uma instrumentalização para a nossa vanguarda, o modernismo brasileiro.

\section{O imaginário cinematográfico de Carlos Drummond de Andrade}

Em 1924, a partir de um primeiro encontro em Belo Horizonte, inicia-se vínculo afetivo duradouro e uma consequente relação intelectual entre Mário de Andrade e Carlos Drummond de Andrade, o qual reconhece no relacionamento o "mais constante, generoso e fecundo estímulo à atividade literária [por ele] recebido em toda a existência”. ${ }^{44}$ Em permanente contato epistolar, eles puderam trocar ideias não só relativas à vida pessoal, como também, e de forma ampla, a respeito de temas da criação literária e, regularmente, sobre a produção poética de cada um. Mário leu e opinou sobre os poemas que constituiriam o primeiro livro de Drummond, Alguma poesia (1930). Daí em diante, ambos leram-se mutuamente, em cumplicidade fraterna que se estendeu até 1945, com a morte de Mário. Essa produtiva parceria, perceptível tanto nas cartas quanto nos textos produzidos por ambos no período em que se corresponderam, determinou afinidades que marcaram fundo suas poéticas. Considerando o amigo como um "professor de nova espécie" (1988, p. 12), Drummond articula-se também com o pensamento de Mário sobre a importância da linguagem do cinema e, precisamente, da obra de Charles Chaplin para a reflexão sobre a vida e a poesia modernas. ${ }^{25}$ Já em seu livro de estreia, ${ }^{26}$ lê-se o poema "Balada do

${ }^{24}$ Cf. "Apresentação", paratexto de Carlos Drummond de Andrade para o livro A lição do amigo: cartas de Mário de Andrade a Carlos Drummond de Andrade (organização e notas do próprio Drummond, 1988). Ainda que não tivessem se encontrado pessoalmente muitas vezes, mantiveram correspondência constante, desde novembro de 1924 até dois dias antes da morte de Mário. O conjunto das cartas trocadas entre eles encontra-se publicado em Correspondência de Carlos Drummond de Andrade e Mário de Andrade, 2003.

${ }^{25}$ Nesse primeiro livro, que é dedicado ao interlocutor missivista ("A Mário de Andrade”), podem ser lidos poemas circunstanciados tanto ao cinema de forma geral quanto a personagens fílmicas em especial ("Lanterna mágica"; "Europa, França e Bahia”; "Balada do amor através das idades"; "O amor bate na aorta”). E no qual está "Explicação", em que o eu-lírico revela chaplinianamente que seu verso "às vezes tem o ar sem-vergonha de quem vai dar/ uma cambalhota,/ mas não é para o público, é para mim mesmo essa/ cambalhota./ Eu bem me entendo./ Não sou alegre./ Sou até muito triste./ [...] Estou no cinema vendo fita de Hoot Gibson,/ de repente ouço a voz de uma viola...[...]".

${ }^{26}$ É nessa primeira reunião de seus poemas que está "A Carlito", ode lírica ao personagem chapliniano, em que Drummond reconhece que "agora é confidencial o teu ensino/ [...], errante poeta desengonçado". E no qual se encontra também o poema "Mário longínquo", 
amor através das idades" ([1924, 1930] 1976, p. 22), no qual Mário identificara - em carta de 1924 - uma "vingança" do amigo contra a "vida besta", saudando a forma com que, por imagens líricas, mas plenas de "humour", ele "retratou a sua própria vida e seus desejos" ([1924]1988, p. 152). Ao cantar o amor nessa balada, o poeta utiliza um artifício temático inusitado: faz corresponder as "idades temáticas do cinema", expressas por cinco filmes cronologicamente poetizados, às idades cronológicas do eu-lírico. Mais do que para celebrar o amor através dos tempos, das “idades", a estratégia serve ao poeta para pensar sobre a transformação do sentimento de amor desde o contexto helênico até o dos heróis modernos. Para isso, instala sua lira na precariedade de um dos marcos da modernidade, o próprio cinema, subvertendo parâmetros da tradição lírica ao abordar o tema do amor sob a ótica da "máquina de criar emoção", já vislumbrada por Mário: o cinematógrafo.

Recriada pela palavra em signos negros no écran de páginas brancas, a figura de "Carlitos" é recorrente em Drummond, chegando mesmo a se constituir como um "outro eu lírico", o duplo "Carlos", poeta desengonçado, personagem gauche, predisposto à galhofa, ao humor e à ironia comuns ao herói fílmico e a esse displaced disfarçado. ${ }^{27} \mathrm{Se}$, na diretriz da "estética da simultaneidade" engendrada por Mário para o exercício experimental de sua "poesia de circunstância", Chaplin é o "professor do século XX", o ensinamento também será aproveitado por Drummond na construção de seu imaginário poético e no jogo verbal em verso. Nessa sucessão de afinidades estéticas, José Guilherme Merquior reconhece que, em Drummond, ainda que distanciado do "poliformismo pregado por Mário de Andrade, [...] a estética simultaneísta é igualmente fonte de certos procedimentos estilísticos específicos" (1976, p. 11). De qualquer forma, incorporando à sua poética signos negros que só existem se iluminados pela luz lunar que eles buscam nas salas de cinema, colocando-se, assim, na esteira da definição proposta

em que lamenta a falta do "ensino cantante" da obra do amigo distante.

${ }^{27}$ No ensaio "O tempo restaurado pela memória cinematográfica na poesia de Carlos Drummond de Andrade," in: Revista Letras \& Letras, 2007, demonstro como o eu-lírico drummondiano incorpora ao displaced Carlos o poeta-vagabundo chapliniano, ambos gauches ("desengonçados") na vida e na arte. Analisando o percurso dessa construção desde Alguma poesia (1930) até Amar se aprende amando (1985), concluo ser a invenção da persona Carlos/Carlito uma das máscaras líricas de Drummond, que lhe permitiu ler o mundo também pelo cinema que viu, patenteando poeticamente esse mundo filtrado pelo seu imaginário cinematográfico. 
por Jean Cocteau para o cinema em preto e branco, ambos, Mário e Drummond, localizam-se na corrente intertextual lítero-fílmica cujo fulcro é a figura esbatida em luz e sombra de Chaplin/Carlitos. Em "Canto ao homem do povo Charlie Chaplin", poema de 1945, por exemplo, identificando na imagem de luz projetada em tantas telas de cinema a figura em que "a noite banha a roupa", Carlos vê Carlitos como "condenado ao negro", mas só até o momento em que "a lua pousa em seu rosto"; percebe, então, que, iluminado pela lua, o "rosto caiado" é feito de "lunar matéria" (1976, p. 149).

Tanto na obra em verso como nas crônicas e contos, o cinema é tema constante em Drummond. Cinéfilo e cinemeiro como Mário de Andrade, seria natural, como efetivamente foi, que seu imaginário cinematográfico viesse a repercutir intensamente em sua fatura literária. A aproximação com a linguagem fílmica - pela sua capacidade de promover a sensação de simultaneidade dos acontecimentos, por meio da montagem de imagens fragmentadas em planos e sequências - foi, entretanto, o que possibilitou ao poeta o simultaneísmo pela palavra articulada em versos. Praticando "a violação e a desintegração da palavra”, para usar seus próprios termos (Apud MERQUIOR, 1978, p. 198), o escritor leva em conta apenas "a medida e o impulso determinados pela coisa poética a exprimir". ${ }^{28}$ Artista moderno que era, Drummond, como Mário e Oswald, sempre experimentou tecnicamente. Mesmo muito antes do itinerário da "nova poesia" do concretismo, praticou o jogo com as palavras, incorporando o visual, fragmentando a sintaxe, desarticulando e remontando vocábulos, divertindo-se com a mistura de linguagens, em uma dimensão lúdica que se fará permanente e que transparecerá no metalirismo dos poemas vindos à luz em Lição de coisas, marcados pela falta de pontuação e pela alternância de versos livres com metrificados, os quais revelam, no entanto, uma extraordinária multiplicidade rítmica.

\section{Lição de coisas, lição de cinema: "O padre, a moça"}

É nesse livro, de 1962, ${ }^{29}$ que se encontra o longo poema narrativo, montado em dez partes numeradas, intitulado "O padre, a moça". O conjunto dos po-

\footnotetext{
${ }^{28}$ Em nota introdutória à primeira edição de Lição de coisas, 1962, apud José Guilherme Merquior, "O último lirismo de Drummond", in: Verso universo em Drummond, Rio de Janeiro, 1976, p.198.

29 Para referências neste texto, uso a edição de Lição de coisas, incluída no livro Reunião: 10 livros de poesia, Rio de Janeiro, Livraria José Olympio, 1976, p. 246-277. Todas as citações textuais que se seguem referem-se a essa edição.
} 
emas do volume aparece de forma perfeitamente ordenada, em nove partes, todas identificadas sob títulos temáticos. O texto ora em análise abre justamente a seção denominada "Ato". Os dois paratextos, respectivamente, da seção - "Ato" - e do texto em versos - "O padre, a moça -, anunciam, de imediato, a natureza narrativa do poema. Ou seja, identificam a sucessão de ações que constituirão a história. O movimento poético, correspondendo à continuidade estabelecida no próprio título do poema, dá-se, então, pela eficácia do arranjo formal: lá onde se esperaria um "e" - "o padre $e$ a moça" - o uso de vírgula remete para a sequenciação dos fatos a vir. Efetivamente, a rapidez da ação domina já o que está informado na sintética proposição dos dois primeiros versos: "O padre furtou a moça, fugiu./ Pedras caem no padre, deslizam”. No seguimento dos versos dessa primeira sequência, a velocidade será acentuada em crescendo pela repetição, quatro vezes, de "lá vai o padre". Além disso, a disposição proposicional se mostra plenamente significativa quando a expressão é usada por três vezes seguidas, em um único verso, sem uso de vírgulas: “[...] lá vai o padre lá vai o padre lá vai o padre”. Estabelece-se, assim, pela ausência de conjuntivos gráficos, a tônica poético-narrativa: a da perseguição. Para além do extraordinário uso de parataxe, fica evidente a remissão ao procedimento de montagem de planos cinematográficos, articulação formal de resto já experimentada de forma consequente desde as vanguardas, na tentativa de reproduzir a sensação de simultaneísmo propiciada pela sucessão de imagens fílmicas em ritmo acelerado, ${ }^{30}$ produzindo uma sensação de continuidade narrativa eminentemente visual.

A cadência delirante da fuga e da perseguição, que agora alcança a totalidade do território brasileiro, acelera-se até o final da narrativa. Inserções de planos verbo-visuais rápidos nos permitem acompanhar perseguidos e perseguidores, desde o norte - "Lá vai o padre,/ atravessa o Piauí, lá vai o padre [...]./ Vamos cercá-lo, gente, em Goiás,/ quem sabe em Pernambuco?” - até o sul - “[...] foi visto em Macapá Corumbá/ Jaraguá Pelotas”. Ainda que o ritmo alucinado da sucessão dos fatos narrados seja alcançado tecnicamen-

\footnotetext{
${ }^{30}$ Por Oswald de Andrade, tanto em verso quanto em prosa, como em seu "Manifesto antropófago" (1928) ou no romance Memórias sentimentais de João Miramar (1924); ou por Mário de Andrade, em versos de O clã do jabuti e no experimental Amar, verbo intransitivo (1927), alinhados às tentativas de aproximação da palavra literária aos procedimentos fílmicos desenvolvidos pela avant-garde europeia. Para detalhamento dessas experimentações, ver: João Manuel Cunha, A lição aproveitada: modernismo e cinema em Mário de Andrade, 2011.
} 
te pelo extraordinário uso de enjambements, o que se pode ler, pela disposição gráfica dos signos verbais, é a descrição da decupagem de uma série de imagens conformadas pelo imaginário cinematográfico do poeta-narrador, o Carlos, cinemeiro e cinéfilo desde os primeiros poemas de Alguma poesia. A abrangência do espaço físico narrativo corresponderia, então, por via da unidade formal alcançada, à metafísica que se evidencia, textualmente, nos últimos versos da seção 1: "Longe o padre vai celebrando vai cantando/ todo amor é o amor e ninguém sabe/ onde Deus acaba e recomeça”. São procedimentos formais da técnica de versificação como esses que, de uma forma geral, são retomados por Drummond no desenvolvimento de todo o poema, para alcançar o tom lírico de um texto que se articula no quadro metafísico da questão relativa ao problema da desordem do mundo e da indiferença divina, tema recorrente em sua obra. ${ }^{31}$

No quadro desta discussão, é preciso apontar, ainda, a articulação opositiva que permeia o uso recorrente das noções de "preto" e "branco", matizadas ao longo do poema. O padre é figurado como "coisa preta", visto na "escureza da batina"; e a moça, como tendo a "face dourada por ternos relâmpagos". Ao mesmo tempo, "luz fosforescente" e "luz de danação"; "meia-treva" e "um breve clarear"; "noite" e "espaço sombra"; "noitidão" e "sombra"; "alva" e "branca"; "negra" e "negrumes"; "prismas de luz" e "claridade" são termos que identificam não apenas a fisicidade que compõe o espaço da fuga e da perseguição dos elementos naturais e culturais existentes ao redor do padre e da moça, como também os motivos líricos que constituem a história do "negro amor de rendas brancas" anunciado no incipit do poema. O reiterado emprego de palavras que identificam a oposição entre o branco e o preto serve ao desenvolvimento do tema central - a aposta na prevalência da consciência individual, em detrimento de uma secularmente evidenciada partilha do mundo entre o bem e o mal, entre deus e o diabo, entre a pureza e o pecado, entre a salvação e a danação -, em segmentos antitéticos como em "negro amor de rendas brancas", ou em "diabo em forma de gente, sagrado", ou, ainda, em "onde Deus acaba e recomeça”.

Se pensarmos, como venho enunciando até aqui, que a imageria que preside a poética drummondiana é irreversivelmente cinematográfica, e que

${ }^{31}$ José Guilherme Merquior afirma que é essa especulação filosófica que anima a totalidade dos poemas de Lição de coisas, sendo "O padre, a moça" a "página mestra" do conjunto dessa obra. Cf. Merquior, "O último lirismo de Drummond", in: Verso universo em Drummond, 1976, p. 198-211. 
seu imaginário se configurou basicamente por imagens fílmicas em preto e branco, ${ }^{32}$ vistas, justamente, no tempo crucial de sua formação estética, seria natural pensar, também, que, em "O padre, a moça", esse condicionamento se manifesta de forma arquitextual. ${ }^{33}$ Assim, identificada como lugar poético em que se realiza o encontro de textualidades, a literatura poderia ser vista como escrita de signos pretos projetados com "tinta negra" sobre o branco da página, superfície em que se desenham, provisoriamente, palavras em movimento. Condição essencial para que o imaginário poético de Drummond torne-se visível, apreensível e significante pela luz emanante de um olhar que o ilumina desde o nosso interior e que o descobre para o nosso próprio imaginário.

\section{Lição de literatura: $O$ padre e a moça}

Três anos depois da publicação de "O padre, a moça", um outro Andrade, o cineasta Joaquim Pedro, conta a sua história da fuga e perseguição dos personagens drummondianos por meio de uma escritura feita com "tinta de luz": um texto fílmico iluminado desde o seu interior e escrito com signos pretos para serem projetados sobre o branco da tela, superfície em que se desenham, provisoriamente, formas em movimento. Vindo à luz em 1965, o filme tem como título O padre e a moça. ${ }^{34}$ Desde o paratexto

\footnotetext{
32 Ainda que já circulassem fitas "coloridas" - precariamente, de forma artesanal - desde os anos 1910 até os anos 1950, quando o avanço técnico permite a produção de filmes coloridos em escala industrial, a quase totalidade dos filmes em circuito mundial era finalizada em preto e branco. Por outro lado, é preciso levar em conta que o conjunto de filmes, historicamente considerados como representativos da autonomia estética fílmica, alcançada e exercitada até, pelo menos, o início dos anos 1940, não era fotografado em cores. Esse tempo de sedimentação da autonomia artística da linguagem do cinema vai corresponder praticamente ao período do cinema não falado - o "cinema clássico", estendendo-se até os primeiros anos da década de 1940. Cf. Georges Sadoul, História do Cinema Mundial, 1983; Ismail Xavier, Sétima arte: um culto moderno, 1978. De qualquer forma, os filmes que marcaram profundamente o imaginário drummondiano, como explicitado anteriormente neste texto, não eram coloridos; principalmente os de Charlie Chaplin, por exemplo, que, com exceção de apenas um, o último de sua obra ( $A$ condessa de Hong Kong, A countess of Hong Kong, USA/GB, 1967), nunca filmou em cores.

${ }^{33}$ Uso o termo na acepção de Gérard Genette, expressa em sua "Teoria da transtextualidade, tal como se pode averiguar em Gérard Genette, Palimpsestos: a literatura de segunda mão (extratos traduzidos do francês), 2006.

${ }^{34} \mathrm{O}$ padre e a moça. Argumento, roteiro e direção de Joaquim Pedro de Andrade. Produção: Filmes do Serro, Joaquim Pedro de Andrade, Luis Carlos Barreto. Direção de produção: Raymundo Higino. Fotografia, cenografia, câmera: Mário Carneiro. Montagem: Joaquim
} 
verbal com que é denominado, o filme aponta, ao mesmo tempo, para a relação intertextual que estabelece com os versos de Drummond e para a diferença estrutural em relação ao seu hipotexto literário. O uso do conjuntivo $e$, substituindo a vírgula do título do poema, evidencia a qualidade extensiva dos fatos a serem narrados. No poema, a enformação em versos atende ao caráter sintético dos procedimentos próprios a esse tipo de composição literária. Os fatos são apreendidos em continuidade, a partir de recorte preciso em fluxo temporal e espacial que restringe a ação desde a fuga dos personagens, e não explicitam as circunstâncias pregressas do encontro entre os dois. O narrador fílmico, no entanto, atendendo à necessidade arquitextual própria ao meio expressivo que pratica - a de apresentar por imagens os mecanismos psicológicos que embasam o drama do casal -, precisa inventar fatos que esclareçam e sustentem a verossimilhança do que se conta. A trama, então, é construída pela presentificação de acontecimentos anteriores à situação-limite de fuga e perseguição. Por outro lado, entretanto, assim como em "O padre, a moça" se identificaria a vontade de cinema, pelo exercício de recursos próprios à linguagem poética verbal, comensurados à sensação de simultaneidade cinematográfica, como vimos, no texto de Joaquim Pedro fica evidenciada a vontade de literatura. Se no incipit - "apresentação dos créditos" 35 - já se informava que $O$ padre e a moça é "sugerido pelo poema de Carlos Drummond de Andrade", é ao final da narrativa, em uma espécie de epígrafe às avessas, que o diretor imprime signos verbais que presentificam em imagem a palavra poética de "O padre, a moça". ${ }^{36}$ Por meio da inserção de explicit intertextualizado

Pedro de Andrade, Eduardo Escorel. Direção musical: Guerra Peixe. Música: Carlos Lyra. Continuidade: Carlos Alberto Prates Correia. Assistente de direção: Eduardo Escorel. Elenco: Helena Ignez, Paulo José, Mário Lago, Fauzi Arap, Rosa Sandrini, moradores de São Gonçalo do Rio das Pedras. A ficha técnica, transcrita na caixa do DVD, não informa a vinculação do filme com o poema de Carlos Drummond de Andrade. Cópia restaurada, Videofilmes; 90 min., p\&b, [1965] 2009.

35 Os vocábulos "créditos" e "genérico", na acepção em uso na língua portuguesa, corresponderiam à denominação norte-americana (credits) e à francesa (générique), respectivamente, expressando "enumeração dos atores, músicos, diretores, técnicos etc., que participaram da realização de um determinado filme”, cf. Novo Dicionário Eletrônico Aurélio, versão 6.0, 4. ed., 2009. Esse espaço, inicialmente visto como meramente informativo, incluiria também título do filme, epígrafes verbais e outras informações, podendo aparecer tanto no início quanto ao final da película.

${ }^{36}$ Quando de seu lançamento, o filme recebeu de Carlos Drummond de Andrade poemacomentário intitulado "Em preto e branco": "O padre e a moça no cinema./ Emoção mais 
visualmente pela transposição literal de versos que sintetizam o poema de Drummond, o cineasta conclui sua narrativa dos amores "que se esfumam no ar". E o faz por meio de estratégia autoral que, sem deixar de ser absolutamente fílmica, expressa o seu desejo de literatura, de poema, de poesia do poema. ${ }^{37}$ É de se notar que o tratamento dado pelo cineasta ao espaço dos "créditos", vistos aqui como incipit e explicit narrativos, transforma esse "espaço" informativo em "lugar" diegético. Ou seja, constitui-se como uma hibridização de escritura verbal com figuração fílmica, produzindo uma clivagem discursiva entre enunciação e diegese, contaminando mutuamente os dois elementos - palavra e imagem - e transferindo as propriedades de um a outro. Ao conformar o texto verbal em imagem fílmica, transforma-se o leitor em espectador. ${ }^{38}$

A última sequência desse exercício de transcriação ${ }^{39}$ coincide com o que se conta na última parte do poema: padre e moça, acuados pelos persegui-

funda quem há de/ sentir ante este filme-poema?/ Salve, Joaquim Pedro de Andrade!", publicado em Carlos Drummond de Andrade, Versiprosa: crônica da vida cotidiana e de algumas miragens, Rio de Janeiro, 1967. Da mesma forma, quando o filme sofre restrições por parte da censura oficial vigente na época, bem como por parte da crítica conservadora e moralista, o poeta manifesta-se publicamente: "[O padre e a moça] É, inicial e fundamentalmente, uma criação artística, e constitui um esforço de compreensão e apresentação, em termos estéticos, de um caso psicológico de intensa dramaticidade, conflito não inventado pelo diretor nem pelo autor do poema, pois dera nome a uma gruta na Bahia e se insere na problemática humana de qualquer tempo ou lugar, saindo da vida para a literatura e a arte". Cf. Carlos Drummond de Andrade, in: Imagens perseguidas: O padre e a moça, Correio da Manhã, 5 jun. 1966. Ambos os textos de Drummond estão disponíveis em: <www.carlosdrummond.com.br>. Acesso em: 23 set. 2010.

${ }^{37}$ A aproximação cinema-poesia estabelecida aqui não se coaduna com a construção do cineasta Pier Paolo Pasolini, expressa em 1965, quando participou de mesa-redonda no Festival de Cinema de Pesaro, na Itália, juntamente com Umberto Eco e Gilles Deleuze, em que apresentou e discutiu o conceito de "cinema de poesia". O resultado de sua manifestação foi publicado em artigo justamente intitulado "Cinema de poesia", no qual ele defende a hipótese de que certo tipo de cinema, como em filmes de Luis Buñuel, Michelangelo Antonioni e Glauber Rocha, por exemplo, poderia ser compreendido a partir do mesmo ponto de vista linguístico utilizado na distinção entre prosa e verso literários. Para aprofundamento da questão, ver: Pier Paolo Pasolini, Empirismo eretico, 1972.

${ }^{38}$ Sobre a natureza do tratamento figurativo imprimido às palavras, no espaço dos "créditos" fílmicos, ver: Laurence Moinereau, Le générique du film: de la lettre à la figure, 2009.

${ }^{39}$ Uso o termo na acepção proposta por Haroldo de Campos, em ensaios publicados em $A$ arte no horizonte do provável (A poética da tradução), 1969; e em Metalinguagem, 1976; bem como no sentido de "tradução criativa", tal como foi desenvolvido por Julio Plaza, em Tradução intersemiótica, 1987. 
dores, refugiam-se em uma gruta. À entrada, “o crepitar da lenha pura” produz "fumo de suave sacrifício". Do lado de fora, "eis que os perseguidores se persignam", enquanto os perseguidos definham em "desfalecimentos teresinos". No último plano, o preto e o branco das formas em pedra da gruta unem-se no cinza da fumaça que invade o local e a tela; as duas figuras, reunidas em preto e branco, contrastadas pela luz em esconso, mas ainda visualizáveis, dissolvem-se em matizes cinzentos e desaparecem sob a luz difusa que agora não mais as revela. É sobre um fundo ainda não uniformemente cinza, então, que se inscrevem, em letras negras, os versos-síntese do poema: "aquele um/ negro amor de rendas brancas". No jogo intertextual inventado pelo cineasta, por meio de um corte rápido em fade out, a imprecisão de brancos, pretos e cinzas da fumaça em movimento que domina o plano define-se em uma superfície compacta de preto, em que a escrita dos versos do poema aparece então em branco. Letras, palavras, verso-poesia-literatura sobre fundo da tela agora negra. A última imagem do filme instala a palavra escrita como lugar diegético figurado, recuperando-a poeticamente: vontade de literatura na construção da palavra branca sobre o fundo negro do écran fílmico.

\section{Conclusão}

No momento em que me encaminho para o final desta reflexão, é preciso, ainda, referenciar sequência fílmica a qual considero como fundamento inventivo para que se perceba o alcance e a qualidade poética da leitura que o cineasta Joaquim Pedro de Andrade produz para os versos de Carlos Drummond de Andrade. Trata-se do segmento imediatamente anterior à perseguição final que culminará com a asfixia dos amantes encurralados na gruta enfumaçada. A sequência é montada por oito planos que articulam imagens que refletiriam em luz e sombra o verso-mote do poema drummondiano: "aquele um/ negro amor de rendas brancas". Assim: enquadramento aproximado do rosto da moça, banhado pela luz do sol, os cabelos ao vento leve, enredando-se em renda; o roçar dos lábios do padre no ombro ensolarado da moça; o êxtase no brilho do olhar da moça; close do rosto banhado em luz, inclinando-se; o corpo nu deitado sobre um leito de flores miúdas, rendando em branco o fundo negro da roupa do padre; close das dezenas de florinhas em primeiro plano, projetando-se como rendilhamento em branco sobre a batina preta do padre, vista em segundo plano; ao fundo, o rendado de pedras brancas sobre a montanha em negro, 
o contorno escuro da pedra picotando o céu claro. O tracejar de signos com tinta negra sobre o branco da tela, sendo, assim, um ato de escritura, produção textual que só existe entre a obscuridade e a claridade, entre o preto e o branco, entre a escuridão e a luz. Intersecção de textualidades em que se inscreve o encontro poético entre "O padre, a moça" e O padre e a moça. Permanência da poesia na tradução do literário ao fílmico, possibilitada pela vontade de cinema na literatura e pelo desejo de literatura no cinema.

\section{Referências Bibliográficas}

ANDRADE, C. Drummond de. Alguma poesia. In: Reunião: 10 livros de poesia. 7. ed. Rio de Janeiro: José Olympio, 1976.

. Apresentação. In: A lição do amigo: cartas de Mário de Andrade a Carlos Drummond de Andrade. 2. ed. rev. Rio de Janeiro: Record, 1988. p. 9-12.

. Versiprosa: crônica da vida cotidiana e de algumas miragens. Rio de Janeiro: José Olympio Editora, 1967.

ANDRADE, Mário de. A escrava que não é Isaura [1922-1924]. In: Obra imatura; Obras completas. v. I. São Paulo: Martins; Belo Horizonte: Ed. Itatiaia, 1980.

O baile das quatro artes [1943]. In: Obra imatura; Obras completas. São Paulo: Martins; Belo Horizonte: Ed. Itatiaia, 1980. v. XIV

BAUDELAIRE, Charles. Le public moderne et la photographie, Salon de 1859. In : Oeuvres completes. Paris: Galimard, Bibliothèque de la Pléiade, 1961.p. 1031-1036.

. Salão de 1859. In: Obras estéticas: filosofia da imaginação criadora. Trad. Edison Heldt. Petrópolis: Vozes, 1993. p. 83-147.

BENJAMIN, Walter. Passagens. Trad. Irene Aron; Cleonice Paes Barreto Mourão. Belo Horizonte: Editora UFMG; São Paulo: Imprensa Oficial do Estado de São Paulo, 2006.

BRETĖQUE, F. Amy de la. Le cinéma, l'encre, la lune et les statues. In : COCTEAU, Jean. Une encre de lumière. Montpellier: Centre d'Études Littéraires Françaises du XXème Siècle/Université Paul Valéry, 1989. p. 6-10.

BUCK-MORSS, Susan. Dialética do olhar: Walter Benjamin e o projeto das 
passagens. Trad. Ana Luiza Andrade. Belo Horizonte: Editora UFMG, 2002. CAMPOS, Haroldo de. A arte no horizonte do provável. São Paulo: Perspectiva, 1969.

CANUDO, Ricciotto. L'usine aux images. Genève: Office Central d'Editions, 1927.

COCTEAU, Jean. Une encre de lumière. Montpellier: Centre d'Études Littéraires Françaises du XXème Siècle/Université Paul Valéry, 1989.

COMMENT, Bernard. Le XIXe siècle des panoramas. Paris: Adam Biro, 1993.

CUNHA, J. M. dos S. Cunha. Avant-garde, literatura e cinema. O olho da História, EDUFB/CNPq, Bahia, v. 10, n.6, p. 1-19, 2004.

. A lição aproveitada: modernismo e cinema em Mário de Andrade.

São Paulo: Editora Ateliê, 2011.

. O tempo restaurado pela memória cinematográfica na poesia de Carlos Drummond de Andrade. Revista Letras \& Letras, UFU-ILL, Uberlândia, v. 23, n. 2, p. 111-133, jul./dez. 2007.

ESCOREL, Eduardo. A décima musa. Revista Novos Estudos, Cebrap, São Paulo, n. 35, p. 171-180, 1993.

GENETTE, Gérard. Palimpsestos: a literatura de segunda mão. Trad. Luciene Guimarães; Maria Antônia Coutinho. Belo Horizonte: PostLit -Fale/ UFMG, 2006.

KLAXON. 1922-1923, ed. fac. São Paulo: Secretaria da Cultura, Ciência e Tecnologia do Estado de São Paulo, 1976.

LOPEZ, T. P. Ancona. Uma difícil conjugação [1981]. In: ANDRADE, Mário de. Amar, verbo intransitivo. 17. ed. Belo Horizonte: Villa Rica, 1991. p. 9-44. MERQUIOR, J. Guilherme. Verso universo em Drummond. Trad. Marly de Oliveira. 2. ed. Rio de Janeiro: Livraria José Olympio, 1976.

METZ, Christian. Linguagem e cinema. Trad. Marilda Pereira. São Paulo: Editora Perspectiva, 1980.

MOINEREAU, Laurence. Le générique du film: de la lettre à la figure. Rennes: Presses Universitaires de Rennes, 2009. 
PASOLINI, P. Paolo. Empirismo eretico. Milão: Garzanti, 1972.

PERRONE-MOISÉS, Leyla. Altas literaturas: escolha e valor na obra crítica de escritores modernos. São Paulo: Companhia das Letras, 1998.

PLAZA, Julio. Tradução intersemiótica. São Paulo: Perspectiva, 1987.

RAMIREZ, Francis. Apollinaire et le désir de cinéma. Cahiers de l'Association Internationale des Études Françaises, Paris, n. 47, p. 371-389, mai. 1995. Separata.

. Poésie et cinema. In: Le cinéma au rendez-vous des arts: cinéma et littérature; France: anées 20 et 30. Paris: Bibliothèque Nationale de France, 1995, p. 31-40. Separata.

ROBINCHON, François. Le panorama, spectacle de l'histoire. Le mouvement social, Paris, n. 131, p. 65-86, avr.-juin., 1985.

SADOUL, Georges. História do cinema mundial. Lisboa: Livros Horizonte, 1983.

SANTIAGO, Silviano (Org. e notas). Correspondência de Carlos Drummond de Andrade e Mário de Andrade. Rio de Janeiro: Bem-Te-Vi, 2003.

XAVIER, Ismail. Sétima arte: um culto moderno. São Paulo: Perspectiva/ Secretaria de Estado da Cultura, 1978. 